\title{
Effect Of Authentic Leadership Style On Employee Engagement In Public Secondary Schools, Murang'a County, Kenya
}

\author{
Monah Maundu \\ Jomo Kenyatta University of Agriculture and Technology (JKUAT), \\ Nairobi Kenya \\ Prof. Gregory S. Namusonge \\ Jomo Kenyatta University of Agriculture and Technology (JKUAT), \\ Nairobi Kenya \\ Dr. Alice N. Simiyu \\ Jomo Kenyatta University of Agriculture and Technology (JKUAT), \\ Nairobi Kenya
}

\begin{abstract}
This study sought to examine the effect of employee authentic leadership style on employee engagement in public secondary schools of Murang'a County in Kenya. A survey research design was employed. The target population was 3,860 teachers. Systematic random sampling followed by use of random numbers were applied to sample 368 respondents in 306 Public Secondary Schools. Data analysis was carried out using descriptive statistical methods that provide measures of central tendency like the mean, standard deviation and percentages to describe the characteristics of the variables of interest in the study. The inferential statistical tools applied in this research were correlation analysis and linear regression. Statistical Package for the Social Sciences software (SPSS) version 23 was used to assist in data analysis. The result showed that authentic leadership had a positive significant effect on employee engagement and its dimensions. Based on the findings of this study, it was established that using authentic leadership style could enhance employee engagement. This study contributes to the general understanding of leadership behaviors that are significant in encouraging employee engagement to both practicing and aspiring school leaders and teachers, and professional educator preparation programs.
\end{abstract}

Key Words: Authentic, Leadership, Employee Engagement, Teachers, Principals, Secondary Schools

\section{INTRODUCTION}

Employee engagement is a matter of concern for leaders and managers in organizations across the globe as they recognize that it is a vital element affecting organizational effectiveness, innovation and competitiveness [28]. Employee engagement is a strategic approach for driving improvement and encouraging organizational change [23]. 'Engaged' employees are more productive, engender greater levels of customer satisfaction, are more likely to lead to organizational success and are key to ensuring that an organization wins the customer loyalty [9].

According to [10], engaged workplaces can also boost economies but the sad reality is that only 13 percent of employees worldwide are engaged in their jobs and the vast majority of employees worldwide, are emotionally disconnected from their workplace and are less likely to be productive. Other similar studies by the Gallup Organization have reported that about 
$20 \%$ of U.S. employees are disengaged, $54 \%$ are neutral about their work, and $26 \%$ are actively engaged [13]. [25] found similar engagement behavior, with $19 \%$ of U.S. workers categorized as disengaged, $54 \%$ as moderately engaged, and only $17 \%$ as highly engaged. This low rate of engagement has continued to be found on many other surveys conducted in the last decade and represents a global crisis in productivity and worker well-being [2].

Management practices have shifted so that the old maxim: 'when an employee sells his labour, he also sells his promise to obey commands' no longer holds true [9]. [8] state that traditional models of hierarchical and legitimate power practices are being challenged as a new generation of workers enters into the workplace. Employees have higher expectations about participating in organizational decision making, pursuing dynamic involvement in organizational activities, and actively seeking work contexts where they believe they are treated with respect and fairness [8]. According to [24], leading this new and evolving workforce requires new perspectives of leadership as well as new scaffolding for understanding the complexities of leadership development in an evolving landscape. Employees now have more choice in where and how they work. As a result, the demands of leadership have evolved [1] and must be viewed from this new perspective and context if they are to match the dynamics of the emerging workplace.

One of the seven principles in the ISO 9001:2015 standard is employee engagement. In the ISO 9001:2008 standard, which is the predecessor of ISO 9001:2015, the same principle was referred to as employee involvement. It implies that there is need for organizations to move from mere employee involvement and embrace employee engagement which is associated with enhanced employee outcomes for the benefit of the employees, the organization and all other stakeholders.

Thus the challenge for business today is not just on satisfying employees and getting them to stay with the organization but to create the environment where they want to and do give discretionary effort to go above and beyond what is written in their job description [9]. This is in agreement with [6], who argues that today's competitive work environment requires organizations to move beyond just motivating their employees and towards creating an environment of engagement

The teacher is a very important resource in the education system. This means that, efficient teacher management and utilization is critical to the quality of learning outcomes. As leaders of their schools, principals are charged with the responsibility of developing an educational environment that ensures satisfaction and raises organizational commitment [4]. Attempts to raise employee engagement levels are to founder unless there is a willingness and energy at a senior level in any organization to take a holistic and long-term approach to building commitment to the organization [9]. Companies that focus on building engaging leaders will see an exponential impact on employee engagement [15.

When supervisors exhibit more relationship related behaviours towards employees, a higher level of engagement is observed in them [5]). There is a strong need for organizations and managers to therefore focus on 'employee engagement' and leadership behaviours that need to be calibrated often to keep employees engaged. Appropriate leadership styles and human resource practices that drive employee engagement need to be put in place in organizations to drive performance [22]. However, there is a discrepancy between the perceived importance of employee engagement and the level of engagement that exists in Public Schools and other organizations today, posing a big gap that is critical in influencing institutional performance. 


\section{Statement of the problem}

School leaders should always work consciously toward creating congruency between organizational and individual needs fulfillment for improved productivity [29] in an effort to increase the level of teacher engagement. Despite efforts by the government of Kenya to increase teachers' salaries, train teachers, provide bursaries through Ministry of Education and Constituency Development Funds to improve access, participation, and performance of students in national examinations, reports on teacher absenteeism, teacher dissatisfaction and high turnover, and poor performance in national examinations are common and these could be indicators of low levels of teacher engagement. Disengaged teachers will produce a low number of matriculation grades and high numbers of form four graduates who are not able to further their education given the current Commission for University Education (CUE) entry requirements to colleges and universities, implying a high wastage rate. This is likely increase the level of unemployment in Kenya due to lack of necessary and relevant education and skills. Unemployment is likely to lead to increased levels of crime, drug abuse and slow economic growth. Leadership style has been linked to teacher dissatisfaction [4] and is also a predictor of employee engagement [29]. According to the researcher, not much has been done to study teacher engagement in public schools in Kenya. This study was therefore to determine the relationship between transformational leadership and employee engagement in public secondary schools of Murang'a County, Kenya.

\section{Research Objective}

The objective of this study was to determine the effect of authentic leadership style on teacher engagement in public secondary schools of Murang'a County.

\section{LITERATURE REVIEW}

Authentic leadership is inspiring, motivational, compassionate, service-oriented and visionary [12]. It combines ethical and transformational leadership qualities. Authentic leadership is a pattern of leader behavior that is characterised by self-awareness, an internalized moral perspective, balanced processing of information, and relational transparency [26]. Selfawareness refers to the ability to show an understanding of how one derives and makes meaning of the world and how this influences the way one views himself or herself over time. It also shows that a leader understands his/her strengths and weaknesses and the multifaceted nature of the self through exposure to others, and being cognizant of one's impact on other people [17].

Relational transparency refers to presenting one's authentic self (not a fake or distorted self) to others. Such behavior promotes trust explained by openly sharing information and expressions of one's true thoughts and feelings while at the same time trying to control display of inappropriate emotions [17]. Balanced processing implies that a leader will objectively analyze all relevant data before making a decision. Balanced processing of information, transparency in relationships, and consistency between values, words, and deeds exhibited by authentic leaders instill elevated levels of commitment, willingness to perform extra-role behaviors like citizenship, and satisfaction with the supervisor among followers (Walumbwa et al., 2008) and can thus increase employee engagement levels [14]. Internalized moral perspective refers to internalized self-regulation which is guided by internal moral standards and values versus group, organizational, and societal pressures. Internalized moral perspective results in expressed decision making and behavior that is consistent with these internalized values $[3,14]$. Research on the relation between authentic leadership and follower work attitudes and behaviors is still scarce due to the novelty of the construct. From this literature, the following conceptual frame is developed. 


\section{Conceptual framework}

\begin{tabular}{|c|c|}
\hline Authentic Leadership & Employee Engagement \\
\hline $\begin{array}{l}\text { Relational transparency } \\
\text { Internalized moral perspective } \\
\text { Balanced processing }\end{array}$ & $\begin{array}{l}\text { Vigor } \\
\text { Dedication } \\
\text { Absorption }\end{array}$ \\
\hline
\end{tabular}

Independent Variable

Dependent Variable

Figure 1: Conceptual Framework

\section{RESEARCH METHODOLOGY}

This research adopted quantitative approach because the data collected through questionnaires from respondents was analyzable using the standard statistical tools. Multistage sampling design was applied so as to first sample the schools (clusters). Cluster sampling technique guarantees that each cluster is represented in the sample and is thus reflects the characteristics of the population with some level of accuracy [18].Out the 306 schools in the county, 92 schools were selected, representing the $30 \%$ recommended by [20]. Random numbers were then used to sample 368 respondents. Pearson correlation analysis was conducted to determine the relationship between employees' perceptions of their leaders' authentic leadership employee engagement. A statistical significance test (at a level of significance of 0.05) was performed to determine if the correlation arrived at was significant or was due to chance in the form of random sampling error by testing hypotheses. Regression analysis was applied to explain the relationship between the independent and dependent variables. F statistic was used to test the significance of the regression model.

\section{Measurement of variables}

Authentic leadership was measured using the Authentic Leadership Questionnaire (ALQ), which is a 16-item theory-driven survey instrument [26] on a likert 5 point scale. The computed Cronbach's alpha coefficient for the variable was 0.918 , which means it is an acceptable level of internal reliability because it is greater than 0.80 [7]. Employee engagement was measured using a self-report questionnaire containing 9 items from Utrecht Work Engagement Scale (UWES) on a Likert 5 point scale. It had a computed Cronbach's alpha coefficient value of 0.897 which was acceptable because it indicated a high internal consistency of the scale used.

\section{Descriptive Statistics on Employee Engagement}

\section{RESEARCH FINDINGS AND DISCUSSIONS}

In this study, any mean score above 3.0 indicated that the respondents agreed with the item on employee engagement under consideration while any mean score below 3.0 showed disagreement. The results in Table 1 show that all the items had mean scores above 3.0 implying that the respondents were positive and generally agreed with the items studied. There was an aggregate score of over 50\% for agree and strongly agree from all the respondents. This implies that most of the respondents were engaged in their work. 
Table 1: Opinions of Respondents on Employee Engagement

\begin{tabular}{|c|c|c|c|c|c|c|c|}
\hline Leadership Item & SD (\%) & D (\%) & N (\%) & A (\%) & SA (\%) & Mean & Std.Dev \\
\hline $\begin{array}{l}\text { At my work, I feel bursting } \\
\text { with energy }\end{array}$ & $10(3.4)$ & $38(12.8)$ & $102(34.5)$ & $116(39.2)$ & $30(10.1)$ & 3.40 & 0.95 \\
\hline $\begin{array}{l}\text { At my job, I feel strong and } \\
\text { vigorous. }\end{array}$ & $5(1.7)$ & $25(8.4)$ & $67(22.6)$ & $150(50.7)$ & $49(16.6)$ & 3.72 & 0.898 \\
\hline I am enthusiastic about my job & $5(1.7)$ & $17(5.7)$ & $50(16.9)$ & $154(52.0)$ & $70(23.6)$ & 3.90 & 0.883 \\
\hline My job inspires me. & $5(1.7)$ & $19(6.4)$ & $52(17.6)$ & $147(49.7)$ & $73(24.7)$ & 3.89 & 0.907 \\
\hline $\begin{array}{l}\text { When I get up in the morning, } \\
\text { I feel like going to work }\end{array}$ & $6(2.0)$ & $18(6.7)$ & $69(23.3)$ & $143(48.3)$ & $60(20.3)$ & 3.79 & 0.905 \\
\hline $\begin{array}{l}\text { I feel happy when I am } \\
\text { working intensely }\end{array}$ & $5(1.7)$ & $16(5.4)$ & $75(25.5)$ & $154(52.0)$ & $49(15.5)$ & 3.74 & 0.845 \\
\hline $\begin{array}{l}\text { I am proud of the work that I } \\
\text { do }\end{array}$ & $2(0.7)$ & $11(3.7)$ & $38(12.8)$ & $155(52.4)$ & $90(30.4)$ & 4.08 & 0.798 \\
\hline I am immersed in my work. & $15(1.7)$ & $26(8.8)$ & $95(32.7)$ & $127(42.9)$ & $43(14.5)$ & 3.60 & 0.900 \\
\hline $\begin{array}{l}\text { I get carried away when I am } \\
\text { working }\end{array}$ & $22(7.4)$ & $74(25.0)$ & $98(33.1)$ & $73(24.7)$ & $29(9.8)$ & 3.04 & 1.090 \\
\hline
\end{tabular}

Source: Field Study, 2018, $\mathrm{n}=296$ Cronbach's Alpha=0.897, SD=Strongly disagree D=Disagree $N=$ Neutral A=Agree SA=Strongly Agree, Std. Dev.=Standard Deviation.

\section{Descriptive Statistics on Authentic Leadership}

The results in Table 2 show that all the studied items had a mean of above 3.0 except 'He/she admits his/her mistakes to others', which had a mean of 2.84. This meant that the responses were positive and the respondents agreed with the items. This implies that school the schools principals were practicing authentic leadership. 
Table 2: Opinions of Respondents on Authentic Leadership

\begin{tabular}{|c|c|c|c|c|c|c|c|}
\hline Leadership Item & SD (\%) & D (\%) & $\mathrm{N}(\%)$ & $A(\%)$ & SA (\%) & MN & SD \\
\hline $\begin{array}{l}\text { Is aware of his/her greatest } \\
\text { weaknesses }\end{array}$ & $24(8.1)$ & $40(13.5)$ & $125(42.2)$ & $75(25.3)$ & $32(10.8)$ & 3.1 & 1.05 \\
\hline $\begin{array}{l}\text { Is aware of his/her greatest } \\
\text { strengths }\end{array}$ & $7(2.4)$ & $25(8.4)$ & $93(31.4)$ & $119(40.2)$ & $52(17.6)$ & 3.62 & 0.942 \\
\hline $\begin{array}{l}\text { Seeks feedback as a way of } \\
\text { understanding who he/she really is } \\
\text { as a person. }\end{array}$ & $34(11.5)$ & $65(22.0)$ & $85(28.7)$ & $86(29.1)$ & $26(8.8)$ & 3.02 & 1.151 \\
\hline $\begin{array}{l}\text { Accepts the feelings he/she has } \\
\text { about him/her self }\end{array}$ & $14(4.7)$ & $46(15.5)$ & $107(36.1)$ & $102(34.5)$ & $27(9.1)$ & 3.28 & 0.990 \\
\hline $\begin{array}{l}\text { His/her actions reflect his/her core } \\
\text { values }\end{array}$ & $8(2.7)$ & $37(12.5)$ & $63(21.3)$ & $146(49.3)$ & $42(14.2)$ & 3.60 & 0.969 \\
\hline $\begin{array}{l}\text { He/she does not allow group } \\
\text { pressure to control him/her. }\end{array}$ & $8(7.7)$ & $25(8.4)$ & $68(23.0)$ & $136(45.9)$ & $59(19.9)$ & 3.72 & 0.967 \\
\hline $\begin{array}{l}\text { Other people know where he/she } \\
\text { stands on controversial issues. }\end{array}$ & $15(5.1)$ & $33(11.1)$ & $97(32.8)$ & $118(39.9)$ & $33(11.1)$ & 3.41 & 0.998 \\
\hline $\begin{array}{l}\text { His/her morals guides what he/she } \\
\text { does as a leader }\end{array}$ & $9(3.0)$ & $23(7.8)$ & $62(20.9)$ & $129(43.6)$ & $73(24.7)$ & 3.79 & 1.00 \\
\hline $\begin{array}{l}\text { He/she seeks others' opinions before } \\
\text { making up his/her own mind. }\end{array}$ & $35(11.8)$ & 41(13.9) & $66(22.3)$ & $109(36.8)$ & $45(15.2)$ & 3.30 & 1.227 \\
\hline $\begin{array}{l}\text { He/she listens closely to the ideas of } \\
\text { those who disagree with him/her. }\end{array}$ & $40(13.5)$ & $56(18.9)$ & $66(22.3)$ & $101(34.1)$ & $33(11.1)$ & 3.10 & 1.229 \\
\hline $\begin{array}{l}\text { Does not emphasize his/her own } \\
\text { point of view at the expense of } \\
\text { others. }\end{array}$ & $36(12.2)$ & $52(17.6)$ & $76(36.1)$ & $107(36.1)$ & $25(8.4)$ & 3.11 & 1.163 \\
\hline $\begin{array}{l}\text { Listens very carefully to the ideas of } \\
\text { others before making decisions. }\end{array}$ & $33(11.1)$ & $43(14.5)$ & $57(19.3)$ & $113(38.2)$ & $50(16.9)$ & 3.35 & 1.237 \\
\hline $\begin{array}{l}\text { Openly shares his/her feelings with } \\
\text { others. }\end{array}$ & $22(7.4)$ & $44(14.9)$ & $60(20.3)$ & $135(45.6)$ & $35(11.8)$ & 3.40 & 1.106 \\
\hline $\begin{array}{l}\mathrm{He} / \text { she lets others know who he/she } \\
\text { truly is as a person. }\end{array}$ & $20(8.8)$ & $53(17.9)$ & $99(33.4)$ & $89(30.1)$ & $35(11.8)$ & 3.22 & 1.085 \\
\hline $\begin{array}{l}\text { He/she says exactly what he or she } \\
\text { means }\end{array}$ & $23(7.8)$ & $31(10.5)$ & $71(24.0)$ & $121(40.9)$ & $50(16.9)$ & 3.49 & 1.126 \\
\hline $\begin{array}{l}\text { He/she admitshis/her mistakes to } \\
\text { others. }\end{array}$ & $54(18.2)$ & $62(20.9)$ & $83(28.0)$ & $72(24.3)$ & $25(8.4)$ & 2.84 & 1.224 \\
\hline
\end{tabular}

Source: Field Study, 2018, n=296 Cronbach's Alpha=0.918, SD=Strongly Disagree $D=D i s a g r e e$ $\mathrm{N}=$ Neutral $\mathrm{A}=$ Agree $\mathrm{SA}=$ Strongly Agree, $\mathrm{MN}=\mathrm{Mean}, \mathrm{SD}=$ Standard Deviation.

\section{Correlation analysis}

The results in Table 3 show that there is a moderate positive correlation $(r=0.431$; $\mathrm{p}$-value $<0.001$ ) between authentic leadership and employee engagement. This implies that $18.57 \%$ $\left(0.431^{2}\right)$ of variation in employee engagement in secondary schools in Murang'a country is explained by authentic leadership of their principals. [27) found similar results. It also implies that an increase in the practice of authentic leadership dimensions will lead to an increase in employee engagement.

Table 3: Pearson's Correlation between Authentic Leadership and Employee Engagement

\begin{tabular}{llll}
\hline Items & & Employee Engagement & Transactional Leadership \\
\hline Employee & Pearson Correlation & 1 & $.431^{* *}$ \\
Engagement & Sig. (2-tailed) & & .000 \\
& $\mathrm{~N}$ & 296 & 296 \\
& Pearson Correlation & $.431^{* *}$ & 1 \\
Transactional & Sig. (2-tailed) & .000 & \\
& $\mathrm{~N}$ & 296 & 296 \\
\hline
\end{tabular}

**. Correlation is significant at the 0.01 level (2-tailed). 
The results in Table 4 show that there is a statistically significant correlation between vigor and authentic leadership $(\mathrm{r}=.440, \mathrm{p}<0.01)$. There is also a statistically significant positive correlation between dedication and authentic leadership $(\mathrm{r}=.436, \mathrm{p}<0.01)$. There is a statistically significant and relationship between absorption and authentic leadership ( $\mathrm{r}=.209$, $\mathrm{p}<0.01$ ). Similar results were obtained by [27] except that their study showed that there was no significant relationship between absorption and authentic leadership.

Table 4: Correlation between the Dimensions of Employee Engagement and Authentic Leadership

\begin{tabular}{ll}
\hline Vigor & $0.440^{* *}$ \\
Dedication & $0.436^{* *}$ \\
Absorption & $0.209^{* *}$ \\
\hline
\end{tabular}
Authentic Leadership

\section{**. Correlation is significant at the 0.01 level (2-tailed).}

\section{Regression Analysis}

Ho1: There is no significant effect of authentic leadership on teacher engagement in public secondary schools of Murang'a County.

Regression analysis was conducted to empirically determine whether authentic leadership was a significant determinant of teacher engagement in public secondary schools of Murang'a County in Kenya. An R squared of 0.431 shows that $18.57 \%$ of the variations in teacher engagement are explained by transformational leadership as indicated in Table 5. It therefore implies that $81.3 \%$ of the unexplained variations in teacher engagement is accounted for by other factors. These findings support other findings by $[14,27,34,38]$. However, the results disagree with those of [25].

Table 5: Regression Results of Authentic Leadership on Employee Engagement

\begin{tabular}{lccccc}
\hline Model & Sum of squares & $\mathrm{df}$ & Mean square & $\mathrm{F}$ & Sig. \\
\hline Regression & 20.510 & 1 & 20.510 & 67.059 & .000 \\
Residual & 89.920 & 294 & .306 & \\
Total & 110.431 & 295 & & \\
$\mathrm{R} .=0.431$ & $\mathrm{R}^{2}=0.186$ & $\mathrm{R}^{2}=0.183$ & & \\
\hline
\end{tabular}

The model was found to be valid $(F(1,274)=67.059$, $p$-value $<0.001)$ as shown in Table .This large F statistic shows that the regression model is robust. These results have the implication that the relationship between authentic leadership and employee engagement is significant and not by chance. In determining the significance of the variables, standardized beta coefficients are used. The fitted model equation is $\mathrm{Y}=0.359 \mathrm{X}_{1}$.

Table 6: Regression Coefficients of Authentic Leadership on Employment Engagement

\begin{tabular}{|c|c|c|c|c|c|}
\hline & Unsta & dized coefficients & Standardized coefficients & & \\
\hline Model & $\mathrm{B}$ & Std. Error & Beta & $\mathrm{t}$ & Sig. \\
\hline (Constant) & 2.488 & .150 & & 16.624 & .000 \\
\hline Authentic leadership & .359 & .044 & $.431^{* *}$ & 8.189 & .000 \\
\hline
\end{tabular}

**. Correlation is significant at the 0.01 level (2-tailed). 
The fitted model equation shows that employee engagement will increase by 0.359 units with one unit increase in standardized authentic leadership style. The model indicates that authentic leadership is significantly explaining the variation in the dependent variable Therefore, hypothesis $\mathrm{H}_{01}$ : there is no significant effect of authentic leadership style on employment engagement is rejected and the conclusion is that authentic leadership style has a significant effect on employment engagement. The high residual sum of squares (89.920) in Table 5 indicates that the model does not explain a lot of the variations in the dependent variable implying that there are other factors that account for a higher proportion of the variation in the dependent variable.

\section{SUMMARY AND CONCLUSIONS}

This study established that authentic leadership has a positive and significant effect on employee engagement. Authentic leadership explains $18.57 \%$ variation in employee engagement. The results also show that the standardized employment engagement will increase by 0.359 units with one unit increase in standardized authentic leadership style. Based on the findings of this study, it is concluded that authentic leadership is a significant determinant of employee engagement in public secondary schools. This study contributes to the general understanding of leadership behaviors that are significant in encouraging employee engagement to both practicing and aspiring school leaders and teachers, and professional educator preparation programs.

\section{RECOMMENDATIONS}

The study established that $18.57 \%$ of teacher engagement was explained by authentic leadership in this study. It is therefore recommended that there is need for the Teachers Service Commission to plan and strategize at the National and County levels on how to train school principals on authentic leadership skills including other teachers that aspire to take leadership positions. To ensure continued practice of the transformational leadership is schools, it necessary that the Teachers Service Commission through the Ministry of Education puts in place organized evaluation strategies that give school principals the opportunity to assess their performance on a regular basis. The '360 degree' feedback system if applied will give the principals a complete knowledge of their skills and strengths as viewed by themselves and others, and thus provide them with an opportunity to become more aware of themselves and keep them on track in practicing appropriate leadership behaviours.

\section{References}

Ardichvili, A., \& Manderscheid, S. V. (2008). Emerging practices in leadership development: An introduction. SAGE Publications Sage CA: Los Angeles, CA.

Attridge, M. (2009). Measuring and managing employee work engagement: A review of the research and business literature. Journal of Workplace Behavioral Health, 24(4), 383-398.

Avolio, B. J., \& Gardner, W. L. (2005). Authentic leadership development: Getting to the root of positive forms of leadership. The Leadership Quarterly, 16(3), 315-338.

Aydin, A., Sarier, Y., \& Uysal, S. (2013). The Effect of School Principals' Leadership Styles on Teachers' Organizational Commitment and Job Satisfaction. Educational Sciences: Theory and Practice, 13(2), 806-811.

Bakker, A. B., Hakanen, J. J., Demerouti, E., \& Xanthopoulou, D. (2007). Job resources boost work engagement, particularly when job demands are high. Journal of Educational Psychology, 99(2), 274.

Batista-Taran, L. C., Shuck, M. B., Gutierrez, C. C., \& Baralt, S. (2013). The role of leadership style in employee engagement.

Bryman, A. (2008). Why do researchers integrate/combine/mesh/blend/mix/merge/fuse quantitative and qualitative research. Advances in Mixed Methods Research, 87-100.

Burke, R. J., \& Ng, E. (2006). The changing nature of work and organizations: Implications for human resource management. Human Resource Management Review, 16(2), 86-94. 
Cook, S. (2008). The essential guide to employee engagement: better business performance through staff satisfaction. Kogan Page Publishers.

Crabtree, S., \& Robison, J. (2013). Engaged Workplaces Are Engines of Job Creation. Gallup Business Journal.

Datche, A. E., \& Mukulu, E. (2015). The effects of transformational leadership on employee engagement: A survey of civil service in Kenya. Issues in Business Management and Economics, 3(1), 9-16.

de Mello e Souza Wildermuth, C., \& Pauken, P. D. (2008). A perfect match: decoding employee engagement-Part II: engaging jobs and individuals. Industrial and Commercial Training, 40(4), 206-210.

Fleming, J. H., \& Asplund, J. (2007). Where employee engagement happens. The Gallup Management Journal, 3(1).

Gardner, W. L., Avolio, B. J., Luthans, F., May, D. R., \& Walumbwa, F. (2005). “Can you see the real me?” A self-based model of authentic leader and follower development. The Leadership Quarterly, 16(3), 343-372.

Hewitt, A. (2014). Trends in Global Employee Engagement Report. Analysis Included, 284, 2010-2012.

KHAN, M. I., TUFAIL, M., QADIR, G., \& KHAN, S. (2016). Transactional Leadership, Transformational Leadership and Employee Engagement: A Case Study of Banking Sector. Discourse, 2(02).

Kernis, M. H. (2003). Toward a conceptualization of optimal self-esteem. Psychological Inquiry, 14(1), 1-26.

Kothari, C. R. (2004). Research methodology: Methods and techniques. New Age International.

Metzler, J. M. (2006). The relationships between leadership styles and employee engagement.

Mugenda, O., \& Mugenda, A. (2003). Quantitative and qualitative approaches: Research methods. Nairobi: Acts Press.

Nwinyokpugi, P. N. (2015). Employee Engagement and Workplace Harmony in Nigeria Civil Service. International Journal of Innovative Research and Development, 4(2).

Popli, S., \& Rizvi, I. A. (2016). Drivers of employee engagement: The role of leadership style. Global Business Review, 17(4), 965-979.

Ram, P., \& Prabhakar, G. V. (2011). The role of employee engagement in work-related outcomes. Interdisciplinary Journal of Research in Business, 1(3), 47-61.

Shuck, B., \& Herd, A. M. (2012). Employee engagement and leadership: Exploring the convergence of two frameworks and implications for leadership development in HRD. Human Resource Development Review, 11(2), 156-181.

Towers, P. (2003). Working today: Understanding what drives employee engagement. Towers Perrin: Stamford CT.

Walumbwa, F. O., Avolio, B. J., Gardner, W. L., Wernsing, T. S., \& Peterson, S. J. (2008). Authentic leadership: Development and validation of a theory-based measure. Journal of Management, 34(1), 89-126.

Wang, D.-S., \& Hsieh, C.-C. (2013). The effect of authentic leadership on employee trust and employee engagement. Social Behavior and Personality: An International Journal, 41(4), 613-624.

Welch, M. (2011). The evolution of the employee engagement concept: communication implications. Corporate Communications: An International Journal, 16(4), 328-346.

Woestman, D. S., \& Wasonga, T. A. (2015). Destructive leadership behaviors and workplace attitudes in schools. NASSP Bulletin, 99(2), 147-163. 